\title{
"The Reality of Education Using "Madrasati" Electronic Platform in the Physical Education Lesson from the Primary School Teachers' Point of View in Taif"
}

\section{Dr. Fahad Jameel Al-Thumali.}

Assistant Professor, Department of Sports Sciences, Faculty of Education, Taif University, Saudi Arabia.

\begin{abstract}
The present study aims to identify the reality e-learning in education using Madrasati (My School) electronic platform in the Physical education lesson from primary school teachers' point of view in Taif, Saudi Arabia. The researcher used a descriptive survey-based research method. Descriptive survey data aims to know the extent to which different conditions can be obtained about the subjects and other variables in a certain situation (Creswell, 2013). In the current study, it is the reality of education using "Madrasati" electronic platform in the physical education lesson from the primary school teachers' point of view in Taif. Hence, this methodology suits the nature of the study. The sample of the present study $(\mathrm{N}=100)$ was randomly selected from primary school physical education teachers in in Taif. The sample was then divided into two groups: first group ( $N=20$ teachers) selected for conducting the pilot study and doing statistical analyses. The second group ( $\mathrm{N}=80$ teachers) was selected for conducting the survey study using the questionnaire. To collect data in the present study, the researcher used a questionnaire, designed by the researcher. The study results indicated that: Madrasati electronic platform helps the teacher exploit time better than the traditional method of teaching physical education lessons. The teacher feels satisfied when teaching the physical education lesson through Madrasati electronic platform. Madrasati electronic platform helps teachers teach efficiently and provide an ideal model of motor skills more than the traditional method of teaching physical education lessons. Using Madrasati electronic platform, physical education teachers could attend some training programs provided by the Ministry of Education using different e-learning teaching tools. Madrasati electronic platform helps teachers make physical education lessons as realistic and effective as the traditional lesson i.e., as in face-to-face attendance. The scientific content of physical education lessons on Madrasati electronic platform does not help teachers teach motor skills to students better than the traditional teaching method and lesson. Student's interaction during physical education lessons is highly influenced by the availability of basic sports and physical capabilities available in the traditional lesson. Moreover, on Madrasati electronic platform, the students are less responsive during physical education lessons compared to traditional teaching method.
\end{abstract}




\section{Keywords: Physical Education - E-Education - Teaching Methods - Distant Learning}

- Electronic Platforms - Educational Platforms - Primary Stage - Descriptive Research

\section{Introduction to the Study:}

According to Williams (2013), the $21^{\text {st }}$ Century has brought changes to education i.e., changes that include greater distance in learning options for primary, middle and high school students. While distance learning has been around for decades, the progressive ways with which students are able to select and complete virtual courses through the internet in nearly every educational area are increasing. Such Innovations and changes in modern technology has led to the emergence of many models and methods of teaching and learning: the concept of integrated education, the CAL (Computer Assisted Learning) concept, the distance education concept through which the student learns anywhere without the need for the teacher's permanent presence, and the concept of E-Learning which relies on using computer's modern techniques and multimedia and the World Wide Web (Vlasova, et. al., 2018). Online physical education presents a unique set of challenges for specialists in transforming traditional physical education into a digital reality, all while meeting the same requirements including curriculum and assessment standards of traditional courses. Currently, limited research exists on investigating the reality and effectiveness of physical education online teaching (Goad \& Jones, 2017).

According to Gibbone and Mercier (2014), modern technology has become the growing digital generations' way of thinking. Adherence to traditional methods of education will definitely lead to a sharp separation between the ways through which students learn in educational institutions and their ways of thinking in the outer world. Therefore, educators and stakeholders should necessarily take advantage of the power of such modern technologies to accomplish desired educational goals, believing in the inevitability of the fundamental transformation of the educational systems to: cope with the new environment, create more friendly and flexible educational environments that have the ability to overcome both time and place. Hence, students would turn into active and productive learners strongly involved in the production of knowledge by investing in the great potential of these modern technologies and the multimedia they provide: images, video, conversation, and direct communication (Kennedy \& Archambault, 2012)

According to Amhag \& Jakobsson (2009), the emergence of E-Learning due to using and activating modern technology in the educational process, the core of which is to uniquely individualize the learning process was supposedly an advantage. Yet, at the onset of the $21^{\text {st }}$ century, as a result of the rapid flow of information and the need to promote students' individual skills, an overwhelming aspiration to reduce the student isolation in the educational process was created by involving the student in active learning with his 
colleagues thus, moving into the stage of interactive and social sharing of knowledge. ELearning is the best way to prepare the future generation for practical and scientific life and in accordance with the current age requirements. The E-Learning educational system seeks to reach its vital goal i.e. the ability to provide and browse most updated information as soon as it appears on the network using the available electronic browsing programs (Hin, et. al. 2009). Consequently, spreading communication among students and matching different and same level groups using rapid evaluation to reach results and correct mistakes. Above all, E-Learning aims at exchanging experiences between educational institutions (Bravo, et. al. 2019).

Barakhsanov, et. al., (2019) argue that one of the most advanced educational systems is the learning platforms, as is considered the most advanced and most popular outcome of modern education technologies. These sites have brought about a major change in teachersstudents communication and information sharing. In addition, such sites have become a world without boundaries helping all to learn unconditionally at any time. It is strongly believed that learning platforms also removed the obstacles and difficulties imposed by the traditional teaching methods and communication channels of the traditional education. All in all, learning platforms are a powerful means of interaction between learners (Clark and Mayer, 2016).

"Madrasati" electronic platform is a distant education system that has been established by Saudi Arabia's Ministry of Education due to the conditions imposed by the Corona virus pandemic to facilitate learning for the primary, preparatory, and secondary school students (Wikipedia, 2021). The e-learning management system, i.e. Madrasati platform is an ambitious project that pursues the benefit of integrating technology in education, to contribute to achieve digital transformation, and to deliver education to students using its multi models (synchronous- non-synchronous) through a unified electronic system (Aseer, 2021).

Accessing "Madrasati" platform is achieved by linking Microsoft account to our "Tawakalna" account created by the "Saudi Authority for Data and Artificial Intelligence". The learners, males or females, access "Madrasati" platform by typing in their private emails sent to them and their passwords. Then, the page allows them access to virtual classrooms, do their home assignments, attempt tests, and ask teachers questions. Accessing Madrasati's virtual classrooms is facilitated by "Microsoft Teams", the system initiated by "Microsoft Corporation". Such a system is well-known for its swiftness and ability to host a huge number of users at the same time.

Physical education, as a special educational curriculum, demands an organized scientific effort to plan its programs, evaluate its results, and determine the extent to which its 
objectives are achieved. At school, the role of physical education is not just engaging in physical activity, but rather to set the basic rules for practicing activities on regular basis, especially during students' early developmental stages. Therefore, it was inevitable that the school physical education curriculum had to be implemented through several stages, starting by providing the correct information based on the scientific basics of physical activity, and ending with the actual practice stage. Consequently, students would develop positive attitudes towards physical education, paving the way for developing programs and various activities for positive participation (Ministry of Education, 2016).

According to the Ministry of Education (2016), the main purpose of Physical education is the ultimate overall balanced development of the individual based on their potentials and capabilities. This would be achieved by active participation in physical education activities that suits the developmental traits of each stage under the supervision of highly qualified educational leaders. Thus, to identify the main goals of physical education in mainstream education, we must embrace a philosophy that views the student as a body, a mind and a soul. Hence, the philosophy of physical education curriculum across all stages of mainstream education is based on the following three basic pillars:

1. Islam, the divine approach that must be the individual's guide in their life, including their physical behavior.

2. National customs and traditions which are necessarily consistent with teachings of Islamic law.

3. Physical activity is necessary for the all human organs to work efficiently and effectively, especially with the technological progress, that might negatively affect human health.

\section{Problem of the Study:}

In order to develop teaching and learning methods in education; promote teachers and students productivity, and increase the effectiveness of educational management and maximize its outcomes, the present study attempts to identify the educational requirements for using educational electronic platforms such as "Madrasati" in the primary stage from the teachers' point of view.

The researcher conducted a pilot study using an open-ended interview with a number of primary school physical education teachers in Taif to identify the reality and effectiveness of "Madrasati" platform during the physical education lesson among primary school students. In addition, the researcher attempted to identify students' interaction level during the physical education lesson using the platform. Therefore, the researcher conducted the present study to identify the reality of education using "Madrasati" electronic platform 
during the physical education lesson from the primary school teachers' point of view of in Taif. So the problem of the present study can be stated as follows"

"Identifying the reality of education using "Madrasati" electronic platform during the physical education lesson from the primary school teachers' point of view of in Taif.

Due to the emergence and importance of e-learning and educational platforms field, a number of recent international studies have been conducted: Gunter \&Reeves (2017), Gutierrez and Torrego (2018), Gogolev et al.,(2015); Schulz, et. al., (2014); Sergin and Khompodoeva (2012); Sergin, and Lytkina (2012); Sergin and Khompodoeva, (2012); Vlasova, et. al. (2019). Most relevantly, Bastila et al. (2014) studied "Accessing to the Global Web-2 (Edmodo) to enhance learning: tracking the teachers' views following use in their classrooms".

Similarly, in the Arab world, a number of studies have been conducted such as AlHammoud's study entitled (2021) "The reality of teacher's distant training using Madrasati electronic platform from their point of view and suggestions for its development". Further, Abdu (2020) examined "The use of Edmodo educational platform in developing of voice awareness and some writing skills among sixth grade students of primary stage". A third study is Ramadan's (2019) entitled "The effectiveness of the flipped classroom strategy based on educational electronic platforms in the developing some computer skills among preparatory school students. Similarly, the study of Omran (2018) is titled "The impact of a teaching program using the interactive educational platform on learning some ball basic skills in the rhythmic artistic exercises among Faculty of physical Education students, Tanta University". The study of Abdul Fattah (2017) is titled "The impact of different interactive educational platforms on developing some computer skills among Educational Technology Students". The last study to mention here is Mohammed's (2012) "The effectiveness of Edmodo website in promoting educational achievement and problemsolving skills in communication skills course among preliminary year students of Imam Mohammed Bin Saud Islamic University".

However, none of this existing body of research has addressed the reality of education using Madrasati electronic platform in the Physical education lesson from the primary school teachers' point of view in Taif.

\section{Significance of the Study:}

\section{A. Theoretical Significance:}

The present study is significant for its contribution to the field of identifying the reality e-learning the reality of education using Madrasati electronic platform in the Physical education lesson from primary school teachers' point of view in Taif. This study would help researchers, teachers, and students make the best of e-learning and educational 
electronic platforms among primary school students in Taif. In addition, it is expected to help develop teaching and learning methods and, above all, help integrate both traditional teaching and learning and electronic teaching and learning under the Corona Virus Pandemic.

\section{B. Practical Significance:}

The present study is practically significant as it contributes to the field by providing researchers and scholars with thorough information about e-learning and educational electronic platform among primary school students in Taif, Saudi Arabia.

\section{Aims of the Study:}

The current study aims to identify the reality e-learning in education using Madrasati electronic platform in the Physical education lesson from primary school teachers' point of view in Taif through:

1. Identifying the reality of the interaction of physical education teachers with Madrasati electronic platform.

2. Identifying the reality of students interacting with the physical education lesson on Madrasati electronic platform.

\section{Questions of the Study:}

To fulfill the aims of the study, the researcher addresses the following questions:

1. What is the reality of the interaction of physical education teachers with Madrasati electronic platform?

2. What is the reality of students' interaction with the physical education lesson on my school's electronic platform?

\section{Procedures of the Study:}

\section{Methodology of the Study:}

The researcher employed the descriptive survey-based research method. Descriptive survey data aims to know the extent to which different conditions can be obtained about the subjects and other variables in a certain situation (Creswell, 2013). In the current study, it is the reality of education using "Madrasati" electronic platform in the physical education lesson from the primary school teachers' point of view in Taif. Hence, this methodology suits the nature of the study.

\section{Sample of the Study:}

The Sample of the present study is primary school physical education teachers in Taif, Saudi Arabia. 
The sample of the present study $(\mathbf{N}=\mathbf{1 0 0})$ was randomly selected from primary school physical education teachers in in Taif. The sample was then divided into two groups: The first group ( $\mathrm{N}=20$ teachers) was selected for conducting the pilot study and doing statistical analyses. The second group ( $\mathrm{N}=80$ teachers) was selected for conducting the survey study using the questionnaire. Table (1) shows description and distribution of the research sample.

\begin{tabular}{|c|c|c|c|}
\hline $\begin{array}{l}\text { Sample Distribution } \\
\text { Study Sample }\end{array}$ & \begin{tabular}{|c} 
Pilot Study \& \\
Statistical Analyses \\
Sample
\end{tabular} & Basic Sample & Total Number \\
\hline \begin{tabular}{|l|} 
Primary School Physical \\
Education Teachers In Taif
\end{tabular} & 20 & 80 & 100 \\
\hline Sum & & & 100 \\
\hline
\end{tabular}

Table (1). Description and Distribution of the Study Sample.

3. Data Collection Tools:

To collect the data of the study, the researcher designed a questionnaire which was prepared according to the following procedural steps:

1- Reviewing the existing literature and the studies related to the study.

2- Conducting open-ended interviews.

3- Identifying the main topics to be covered by the questionnaire (Appendix: 2).

4- Drafting a set of statements representing the main topics of the questionnaire (Appendix: $3)$.

5- Submitting the drafted statements to a jury of experts and specialists to check on its validity and suitability for the study.

6- Conducting statistical analyses to check the validity and reliability of the final questionnaire (Appendix: 4).

8- Presenting the final form of the questionnaire (Appendix: 5).

\section{The Pilot Study}

The researcher administered a Pilot Study to a representing sample of teachers $(\mathrm{N}=20)$, which was the same sample used to perform the questionnaire related statistical 
analyses (Table 1). The Pilot Study was conducted between Wednesday, August $18^{\text {th }} 2021$ and Thursday, August $19^{\text {th }}, 2021$. The Pilot Study aimed to:

1. Identify the basic study sample's understanding of the questionnaire statements.

2. Identify potential difficulties that might occur during the questionnaire administration.

The pilot study results demonstrated that the sample fully understood the questionnaire statements, as none of them inquired about any of the statements.

\section{The Main Study (The Questionnaire Study)}

As all the scientific and administrative requirements and conditions concerning the questionnaire were appropriately addressed, the main study was administered to a sample of teachers $(\mathrm{N}=80)$ as is shown in (Table 1) between Sunday, August $22^{\text {nd, }} 2021$ and Thursday August 26 2021.

\section{Statistical Analyses:}

To analyze the data collected in the present study, the following statistical procedures and treatments were used using the SPSS:

1. Mean Scores.

2. Standard deviations.

3. Correlation Coefficients.

4. Validity (Internal consistency).

5. Reliability Coefficients (Test - Retest Reliability).

6. (Cronbach Alpha Reliability Coefficients).

7. Percentage.

8. Relative Weight.

9. Relative Significance.

10. K2 test. 
8. Results and Discussion

1. Views of the study sample of the reality of the interaction of physical education teachers with Madrasati electronic platform (Table 2).

\begin{tabular}{|c|c|c|c|c|c|c|c|c|c|}
\hline \multirow{2}{*}{ Statement } & \multicolumn{2}{|c|}{ Yes } & \multicolumn{2}{|c|}{ To some extent } & \multicolumn{2}{|c|}{ No } & \multirow{2}{*}{$\begin{array}{c}\text { Relative } \\
\text { Weight }\end{array}$} & \multirow{2}{*}{$\begin{array}{c}\text { Relative } \\
\text { Significance }\end{array}$} & \multirow{2}{*}{ K2 } \\
\hline & Frequency & Percentage & Frequency & Percentage & Frequency & Percentage & & & \\
\hline 1 & 37 & 46.250 & 29 & 36.250 & 14 & 17.500 & 183 & 76.250 & 10.225 \\
\hline 2 & 28 & 35.000 & 36 & 45.000 & 16 & 20.000 & 172 & 71.667 & 7.600 \\
\hline 3 & 13 & 16.250 & 31 & 38.750 & 36 & 45.000 & 137 & 57.083 & 10.975 \\
\hline 4 & 6 & 7.500 & 39 & 48.750 & 35 & 43.750 & 131 & 54.583 & 24.325 \\
\hline 5 & 28 & 35.000 & 44 & 55.000 & 8 & 10.000 & 180 & 75.000 & 24.400 \\
\hline 6 & 35 & 43.750 & 16 & 20.000 & 29 & 36.250 & 166 & 69.167 & 7.075 \\
\hline 7 & 22 & 27.500 & 41 & 51.250 & 17 & 21.250 & 165 & 68.750 & 12.025 \\
\hline
\end{tabular}

Table (2) Frequency, Percentage, Relative Weight, Relative Significance and K2 Value of the study sample views of the reality of physical education teachers' interaction with Madrasati electronic platform (K2 value at level 0.05 - 5.9). 
Table 2 indicates there are statistically significant differences in favor of the study sample's views of the first variable concerning the questionnaire statements related to the reality of the interaction of physical education teachers with Madrasati electronic platform.

Table 2 shows the frequency, percentage and relative weight of the opinions of the study sample related to the topic of the reality of the interaction of physical education teachers with "Madrasati" electronic platform, and that K2 value of (0.05) equals (5.99) less than the calculated K2value, which was limited to (7.075:24.400). In addition, statement (1) represented the highest relative weight (183) and the highest significance $(76,250 \%)$ among all statements of the first topic.

The statement reads "Madrasati electronic platform helps Physical Education teacher exploit time better than the traditional way of teaching Physical Education lesson. Meanwhile, statement (4) represented the lowest relative weight (131) and the least significance (54.583\%) among all the statements of the first topic.

The statement reads "The teacher can evaluate the student's motor skills using my Madrasati electronic platform. Therefore, the results of the all study sample responses were accepted.

The highest percentage of the sample opinions who chose (yes) in statement (1) was (46.250\%) while the lowest percentage was in the statement (4) (7,500\%). Also, the highest percentage of the sample opinions who chose (to some extent) statement (5) $(55.00 \%)$, and the lowest percentage was statement (6) (20.00\%). In addition, the highest percentage of the sample opinions who chose (No) in statement (3) $(45.00 \%)$ and the lowest percentage was the statement (5) (10.00\%).

Table (2) shows that results of the two statements $(1 \& 6)$ indicate that there are statistically significant differences in favor of the study sample views who chose (yes) as the percentage was $(46,250,43,750)$ respectively.

These results indicate that some of the primary school physical education teachers in Taif believe that Madrasati electronic platform helps teachers exploit time better than the traditional way of teaching physical education lessons. Moreover, the teachers, in general, feel satisfied teaching the physical education lessons using Madrasati electronic platform.

As shown in Table (2), the results of the statements $(2,4,5,7)$ indicate that there were statistically significant differences in favor of the study sample views who chose (to some extent) as the percentage value was $(45.00,48.750,55.00,51.250)$ respectively.

These results indicate that some of the primary school physical education teachers in Taif believe that Madrasati electronic platform helps teachers teach efficiently and 
provide an ideal model of motor skills more than the traditional method of teaching physical education lesssons.in addition, the teacher, to some extent, can evaluate the students' motor skills using Madrasati electronic platform. Moreover, using Madrasati electronic platform, physical education teachers could attend some training programs provided by the Ministry of Education on using teaching tools. Above all, Madrasati electronic platform helps teachers make physical education lessons as realistic and effective as the traditional lesson i.e., as in face-to-face attendance.

As shown in Table (2), the result of statement (3) indicate that there were statistically significant differences in favor of the study sample views who chose (No) as the percentage was (45.00).

These results indicate that some primary school physical education teachers in Taif believe that the scientific content of physical education lessons on Madrasati electronic platform does not help teachers teach motor skills to students better than the traditional teaching method.

Harris and Krousgrill (2008) believe that there are three aspects that are basic elements that must be taken into account when using internet in the educational process: faculty member or teacher development; teaching material development; and students' preparation and training. He also believes that faculty member development is the most important of all three aspects as the faculty member is the key to all other aspects. Thus, the faculty member should not only develop himself and his abilities through the educational institution, but also should absorb the reality of developing teaching methods and fully understands the advantages and disadvantages of using the Internet in teaching. This understanding at the part of the faculty member is crucial to planning the transfer to the new teaching model. It is not really appropriate to start using the Internet teaching in the middle of the academic semester. It is more appropriate, for example, to do this at the beginning of the semester based on a clear vision that defines the subject basics, requirements, the required readings, and the assignments that students will have to do during the semester. It is necessary to provide students with the above mentioned duties as early as the first day of the semester, and even before the beginning of the semester.

According to Al-Musa (2002), "the electronic curriculum as a comprehensive educational electronic document that includes text, sound, image and motion and includes all the experiences that students will learn as planned by and under supervision of the school". Similarly, Gutierrez, and Torrego (2018) believe that physical education school programs occupy a prominent position in the first world countries, as it is the complementary part of education, which is only achievable through the study of physical education and all corresponding activities. Although physical education deceptively seems 
to focus on movements, its goals are mental, emotional, social, psychological, and moral (Gogolev, et. al., 2015).

Along the same lines, educational planning is defined as an essential process to accurately reach the desired educational goals when time, effort, and cost are provided. Also, educational planning provides the educational process with the appropriate logical procedures and treats it as a comprehensive system comprising several components working together (Schulz, et al., 2014).

According to Gunter and Reeves (2017), there are many roles for the contemporary teacher as diverse as the new educational innovations bring into the field, including educational, administrative, social, and human roles. Such roles and tasks require a constantly developing teacher able to cope with both learners' and society needs. This is only achievable if the teacher keeps developing at the technological, intellectual, cultural and cognitive global changes levels. Barakhsanov, et. al., (2018) findings indicate that teacher importance is increasing in light of his new imposed roles. The teacher he has become the guide to knowledge sources, the coordinator of the teaching learning processes, and the learner guidance based on the learner's abilities and inclinations.

On the other hand, the results of Al-Qadiri (2017) and Al-Jamni, et al., (2014) studies indicate that using of e-learning in education in the Arab world is below standards. These results are consistent with the study of Mills et al., (2009) indicating the existence of obstacles using e-teaching from the lecturers point of view: the heavy teaching burden and the lack of technical support provided to use the internet in e-teaching.

Basilaia and Kvavadze (2020) studied that the shift from traditional education to online education during the Corona pandemic. The results indicated that the shift was successful and the experience gained in this epidemic can be used in the post-Corona virus crisis era.

In the present study, the researcher believes that e-teaching and e-learning as represented by Madrasati electronic platform helps the teacher exploit time better than the traditional teaching method. However, the nature of the physical education lesson makes the traditional methods of teaching indispensable for students' learning of basic motor skills learning and physical activities prescribed in the curriculum.

This answers the first question of the study: What is the reality of the physical education teachers' interaction "Madrasati" electronic platform? 
2: The views of the study sample of the reality of the students' interaction with the physical education lesson on Madrasati electronic platform: Table (3)

\begin{tabular}{|c|c|c|c|c|c|c|c|c|c|}
\hline \multirow{2}{*}{ Statement } & \multicolumn{2}{|c|}{ Yes } & \multicolumn{2}{|c|}{ To some extent } & \multicolumn{2}{|c|}{ No } & \multirow{2}{*}{$\begin{array}{c}\text { Relative } \\
\text { Weight }\end{array}$} & \multirow{2}{*}{$\begin{array}{c}\text { Relative } \\
\text { Significance }\end{array}$} & \multirow{2}{*}{$\mathbf{K} 2$} \\
\hline & Frequency & Percentage & Frequency & Percentage & Frequency & Percentage & & & \\
\hline 8 & 51 & 63.750 & 23 & 28.750 & 6 & 7.500 & 205 & 85.417 & 38.725 \\
\hline 9 & 4 & 5.000 & 45 & 56.250 & 31 & 38.750 & 133 & 55.417 & 32.575 \\
\hline 10 & 28 & 35.000 & 33 & 41.250 & 19 & 23.750 & 169 & 70.417 & 3.775 \\
\hline 11 & 53 & 66.250 & 14 & 17.500 & 13 & 16.250 & 200 & 83.333 & 39.025 \\
\hline 12 & 48 & 60.000 & 17 & 21.250 & 15 & 18.750 & 163 & 80.417 & 25.675 \\
\hline 13 & 9 & 11.250 & 11 & 13.750 & 60 & 75.000 & 109 & 45.417 & 62.574 \\
\hline
\end{tabular}

Table (3): Frequency, percentage, relative weight, relative significance and K2 value of the views of the study sample of the reality of the students' interaction $(0.05=5.99)$ 
Table 3 indicates there are statistically significant differences in favor of the study sample's views of the second variable concerning the reality of students' interaction with the physical education lesson on Madrasati electronic platform

Table 3 shows the frequency, percentage, relative significance and relative weight of the study sample's views of the second variable concerning the reality of students' interaction with the physical education lesson on Madrasati electronic platform. It also shows that K2 value at 0.05 level equals (5.99) and is less than K2 calculated value, ranged between (25.675: 62.574) across all statements except for statement (10) as the K2 value at 0.05 equals (5.99) which is more than the calculated $\mathrm{K} 2$ value (3.775). Thus, the study sample view of statement (10) was rejected for the weak statistical significance of the sample responses. Meanwhile, statement " 8 " represented the highest relative weight (205) and $(85,417 \%)$ and the most significant among the variable statements.

The statement reads "During the physical education lesson, the student can ask any questions and make any inquiries through Madrasati electronic platform". On the other hand, statement (13) represented the lowest relative weight (109) and (45.417\%) i.e., the least significant among the variable statements. The statement reads: "on Madrasati electronic platform, the student is more responsive during physical education lessons compared to traditional teaching method". Consequently, all results of the study sample responses were accepted except for statement (10).

The highest percentage of the study sample views who chose (Yes) was statement (1) $(46.250 \%)$ but the lowest percentage was for statement (4) $(7,500 \%)$. In addition, the highest percentage of the study sample views who chose (To Some Extent) was for statement (5) (55.00\%), but the lowest percentage was for statement (6) (20.00\%). Moreover, the highest percentage of the study sample views who chose (No) was for statement (3) (45.00\%), but the lowest percentage was for statement (5) (10.00\%).

In table (3), the results for statements $(8,11$, and 12$)$ indicate there were statistically significant differences in favor of the study sample views who chose (Yes) as the percentage was $\mathrm{v}(63,750 ; 66,250 ; 60.00)$ respectively.

These results indicate that some of the primary school physical education teachers in Taif believe that one of the advantages of using Madrasati electronic platform in teaching physical education lessons is that "the student can ask any questions make any inquiries. In addition, that the platform allows motor skills presentation included in physical education lessons at any time. Above all, the student's interaction during physical education lessons is highly influenced by the availability of basic sports and physical capabilities available in the traditional lesson. 
As is shown in table (3), the result for statement (9) indicate that indicates there are statistically significant differences in favor of the study sample's views who chose (To Some Extent) as the percentage was $(56,250)$. This result indicates that some of the primary school physical education teachers in Taif believe that using Madrasati electronic platform in teaching physical education lessons, to some extent, helps students perform motor skills easily.

As shown in table (3), the results for statement (13) indicates that there are statistically significant differences in favor of the study sample's views who chose (No) as the percentage was (75.00). These results indicate that some of the primary school physical education teachers in Taif believe that the students are less responsive during physical education lessons compared to traditional teaching method".

In this regard, Al-Tamimy (2007) states that in electronic education the learner's attitude is active and effective but not negative as it guarantees the learner's participation in the educational process and that he is not just a passive recipient of delivered by the teacher assuring the uniqueness of individual learning and education. Supporting the same conclusion, Picciano et. al., (2014) believe that he learner who receives an educational program using a unique individual learning method, i.e., computer or any other source is at the core of the educational process. Moreover, learning using e-teaching takes into account learners' individual differences; hence the learner learns according to his potential and capabilities.

Akyol and Garrison (2011) findings indicate that the mean scores of the study sample on the e-education variable (pros, cons, and constraints) were high, and the results showed statistically significant differences in favor of the sample responses on the variables (e-learning use, its pros and cons). On the other hand, the study did not show any statistically significant differences in favor of the constraints variable. The results of Bashir's study (2019) concerning e-learning interaction as consisting of a three-factor structure: the learner's interface, feedback interaction, as well as learning content

Draissi and Yong study results (2020) indicated that what makes things difficult is that COVID-19 pandemic still challenges universities to: overcome the difficulties faced by students and professors, to invest in scientific research, and to continue its nonstop efforts to discover a vaccine. Hence, the new teaching methods focused on increasing the students' independence and individuality; the additional duties assigned to professors to keep busily working from home; and providing free access to a few paid e-learning platforms or databases. 
The researcher believes that the students' interaction with e-learning platforms is suitable for theoretical courses and materials, however, as for practical lessons, interaction must be increased through integrating the traditional teaching methods with e-education.

Thus, this answers the second question of the study: What is the reality of students' interaction with physical education lesson using "Madrasati" electronic platform?

\section{Conclusions of the Study:}

Based on the results of the study, the researcher identified the reality of education using "Madrasati" educational electronic platform in the physical education lesson from the primary school teachers' point of view in Taif. This reality might be described as follows:

1. Madrasati electronic platform helps the teacher exploit time better than the traditional method of teaching physical education lessons.in addition, the teacher, generally, feels satisfied by teaching the physical education lesson through Madrasati electronic platform.

2. Madrasati electronic platform helps teachers teach efficiently and provide an ideal model of motor skills more than the traditional method of teaching physical education lessons. In addition, the teacher, to some extent, can evaluate the students' motor skills using Madrasati electronic platform. Moreover, using Madrasati electronic platform, physical education teachers could attend some training programs provided by the Ministry of Education on using teaching tools. All in all, Madrasati electronic platform helps teachers make physical education lessons as realistic and effective as the traditional lesson i.e., as in face-to-face attendance.

3. The scientific content of physical education lessons on Madrasati electronic platform does not help teachers teach motor skills to students better than the traditional teaching method and lesson.

4. One of the advantages of using Madrasati electronic platform in teaching physical education lessons is that "the student can ask any questions make any inquiries. In addition, that the platform allows motor skills presentation included in physical education lessons at any time. Above all, the student's interaction during physical education lessons is highly influenced by the availability of basic sports and physical capabilities available in the traditional lesson.

5. Madrasati electronic platform, to some extent, helps students perform motor skills easily.

6. On Madrasati electronic platform, the students are less responsive during physical education lessons compared to the traditional teaching method. 


\section{Recommendations of the study:}

Based on the results and conclusions of the study, the researcher recommends:

1. Taking advantage of teachers' and students' positive attitudes and recommendations towards e-education.

2. Developing plans and programs to exploit these attitudes and train teachers and students on e-education.

3. Emphasizing the significance of e-education and attracting schools and universities attention towards embracing e-education as a teaching method and a teaching aid, in addition to disseminating electronic culture among students to achieve maximum interaction among them using this type of education.

4. Training and encouraging teachers to communicate with their students through electronic web pages and e-mails, as most students have home internet services.

5. Universities should conduct further research to identify the effectiveness of using eeducation in severe conditions in addition to holding conferences and seminars aiming to develop and promote e-education.

6. Providing an appropriate educational structure for using e-education at schools and universities and removing all human, financial, and technical restraints that strongly hinder e-education spread through all stages and fields of the education system.

\section{Terminology of the Study:}

\section{A. Electronic learning "E-learning":}

"An interactive learner-based learning style, which focuses on the designing the learning environment in a way that facilitates learning using electronic multimedia to provide the learners with special materials and programs to help achieve educational goals inside and outside the educational institution." (Palloff et al, 2007).

\section{B. Madrasati Electronic Platform:}

"An electronic platform that contains virtual classrooms and attached programs, through which teachers teach Saudi Arabia's students males and females" (Al-Hammoud, 2021). 


\section{REFERENCES}

1. Gibbone \& K. Mercier, (2014). Accomplishing PETE learning standards and program accreditation through teacher candidates' technology-based service learning projects. The Journal of Physical Education, Recreation \& Dance, 85(5), (18:22).

2. Abdel Fattah, A. A. (2017). The Impact of the Difference of Interactive Educational Platforms on the Development of Some Computer Skills among Students of Educational Technology. Unpublished Master's Thesis, Faculty of Physical Education, Banha University.

3. Abdo, S. F., (2020). Using Edmodo Educational Platform In Developing Sound Awareness and Some Writing Skills among Primary School Sixth Graders. Unpublished Master's thesis, Faculty of Education, Tanta University.

4. Akyol, Z., \& Garrison, D. R. (2011). Understanding Cognitive Presence in an Online and Blended Community of Inquiry: Assessing Outcomes and Processes for Deep Approaches to Learning. British Journal of Educational Technology, 42(2), (233:250).

5. Al-Hammoud, M. B. A. (2021). The reality of training teachers remotely to use my school's electronic platform from their point of view and proposals for its development, published research, scientific journal, Faculty of Education, University of Assiut, 37 (1), January.

6. Al-Jamni, M.; Ayad, L.; Farhan, R., (2014). The Reality and Development of EEducation in the Arab World. Published Research: $14^{\text {th }}$ Conference of Ministers Responsible for Higher Education and Scientific Research in the Arab World: Development of Open Education and Distance Learning In Universities.

7. Al-Musa, A. A., (2002). The Use of Information Technology and Computers in Basic Education. Arab Education Office for the Gulf States, Riyadh, Saudi Arabia.

8. Al-Qadiri, S. A., (2017). The Reality of E-Education in Scientific Colleges in Jordanian Universities and its Obstacles and Proposed Solutions. Published Research, Studies in Educational Sciences 5 (36).

9. Al-Tamimi, A. I. (2007). The Reality of Using E-Education in the Mathematics Teaching at the Secondary Level in Light of NCTM Standards in Some Selected Countries. Unpublished Doctoral Thesis, Um Al-Qura University, Mecca, Saudi Arabia.

10. Amhag, L. and Jakobsson, A. (2009). Collaborative Learning as a Collective Competence When Students Use the Potential of Meaning in Asynchronous Dialogue. Sweden: Malmo University, the School of Teacher Education: Computers' Education Journal, (52: 656:667). 
11. Aseer Electronic Newspaper (2021). Education sets the date for the training of school leaders, teachers and supervisors to use my school platform. Aseer Electronic Newspaper. Retrieved from the https://1aseer.com/478213, February $15^{\text {th }}$ 2021.

12. Barakhsanov, V.P., Barakhsanova, E.A., Olesov, N.P., \& Prokopyev, M.S. (2018). E-Learning System Application for Physical Education and Sports Specialist Training. Theory and Practice of Physical Culture, 7 (4).

13. Bashir, K. (2019). Modeling E-Learning Interactivity, Learner Satisfaction and Continuous Learning Intention in Ugandan Higher Learning Institutions. International Journal of Education and Development using Information and Communication Technology.

14. Basilaia, G., \& Kvavadze, D. (2020). Transition to Online Education in Schools during Coronavirus (COVID-19) Pandemic in Georgia. Pedagogical Research, 5 (4).

15. Basilaia, M. D.; Vavougios, T., (2014). Accessing the Web-2 Edmodo World to Support Learning: Tracing Teachers' Opinions after using it in their Classes. University of Thessaly Volos, Greece.

16. Bravo, M.P.C., Pons, J.P., \& Pagán, J.B. (2018). The Impact of ICT in the Spanish Education System: A Survey Summery. Distance Learning Journal, 56 (2).

17. Clark, R.C., \& Mayer, R.E. (2016). E-Learning and the Science of Instruction: Proven Guidelines for Users and Designers of Multimedia Learning. John Wiley \& Sons Publications.

18. Creswell, J. W. (2013). Qualitative Inquiry and Research Design: Choosing Among Five

Approaches. Sage.

19. Draissi, Z.; Yong, Q. Z. (2020). COVID-19 Outbreak Response Plan: Implementing Distant Education in Moroccan Universities. School of Education, Shaanxi Normal University.

20. Farouk, S. A. (2020). Using the Educational Platform Edmodo in the Development of Voice Awareness and Some Writing Skills among Sixth Graders in Primary School. Unpublished Master's Thesis, Faculty of Education, Tanta University.

21. Goad, T.; Jones E., (2017). Training Online Physical Educators: A Phenomenological Case Study. Education Research International, .

22. Gogolev, N.E., Glukhareva, M.R., Sabaraikin, S.V., \& Ivanov, Yu.V., (2015). Organizational peculiarities of scientific activities of future specialists in the sphere of physical education and sports. Theory and Practice of Physical Education, 10, (9:10). 
23. Gunter, G.A. \& Reeves, J.L. (2017). Online professional development embedded with mobile learning: An examination of teachers' attitudes, engagement and dispositions. British Journal of Educational Technology, 48, (1305:1317).

24. Gutierrez, M.A., \& Torrego, G.A. (2018). Media education and teacher training. Interuniversity Pedagogical Magazine, 91(32) (1:5).

25. Harris \& Krousgrill (2008). Distance Education: New Technologies and New Directions. IEEE, 96 ( 6) (917: 930).

26. Hin, H.S., Onn, W.C., Alasmri, M \&. (2019). Social Networking Framework for Learning Motivation. Journal of Southwest Jiaotong University, 54 (6).

27. [https://ar.wikipedia.org/wiki/ Madrasati platform for distant education, retrieved January 3rd 2021.

28. Kennedy, K. Archambault L., (2012). Offering Preservice Teachers Field Experiences In K-12 Online Learning: A National Survey of Teacher Education Programs," Journal of Teacher Education, 63, (3) (185:200).

29. Mills, S. J., Yanes, M. J., \& Casebeer, C. M. (2020). Perceptions of Distant Learning among Faculty Members of College of Education. MERLOT Journal of Online Learning and Teaching, 5 (1), (19:28).

30. Ministry of Education (2016). Physical Education Teacher's Guide, king Fahd National Library Index, Riyadh, 1437 Ah -Saudi Arabia.

31. Mohammed, R. R. (2012). The Effectiveness of Edmodo's Website in Developing Educational Achievement and Problem-Solving Skills in the Communication Skills Course among the Preliminary Year Students at Imam Mohammed Bin Saud Islamic University. Unpublished Master's Thesis, Faculty of Social Sciences, Imam Mohammed Bin Saud Islamic University.

32. Omran, M. M. (2019). The Impact of an Educational Program Using The Interactive Educational Platform in Learning Some Ball Basic Skills in Technical Rhythmic Exercises of Female Students of the Faculty of Physical Education at Tanta University. Unpublished Doctoral Thesis, Faculty of Physical Education, Tanta University.

33. Palloff, R. M., Pratt, K., (2007). Building Online Learning Communities: Effective Strategies for The Virtual Classroom. San Francisco, CA: Jossey-Bass,

34. Picciano, A., Dziuban, C., \& Graham, C. (Eds.) (2014). Blended Learning: Research Perspectives. New York: Routledge.

35. Ramadan, N. O. (2019). The Effectiveness of the Flipped Classroom Strategy Based on Electronic Educational Platforms in Developing some Computer Skills among Middle School Students. Unpublished Master's Thesis, Faculty of Education, Ain Shams University. 
36. Schulz, R., Isabwe, G.M., \& Reichert, F. (2014). Supporting teachers' needs within and through E-learning systems. IEEE 2014 International Conference on Web and Open Access to Learning.

37. Sergin, A.A., \& Khompodoeva, M.V. (2012). On the informational support of the process of training specialists in physical education. Pedagogical Informatics, 5, (18:22).

38. Vlasova, E.Z., Barakhsanova, E.A., Goncharova, S., Aksyutin, P., Kuzin, Z., \& Prokopyev, M.S. (2018). Effective adaptive training of students in Russian pedagogical universities to use e-learning technologies. Education, 39 (23), 10.

39. Williams, L. M., (2017). A Case Study of Virtual Physical Education Teachers' Experiences in and Perspectives of Online Teaching. Unpublished Doctoral Dissertation. Department of Physical Education \& Exercise Science, College of Education, University of South Florida, January.

ملخص البحث : يهدف البحث إلى التعرف على واقع التعليم باستخدام منصة ( مدرستي ) الالكترونية لدرس التربية البدنية من وجهة نظر معلمي المدارس الابتدائية بالطائف ، واستخدم الباحث المنهج الوصفي بالأسلوب المسحي ، وتم اختيار عينة البحث بالطريقة العشوائية وبلغ عددهم (100) معلماً من معلمي التربية البدنية بالمدارس الابتدائية بالطائف ، وتم تقسيمهم إلى عدد (20) معلماً لإيجاد المعاملات العلميـة ولإجراء الدراسـة الاستطلاعية ، وعدد (80) معلمـاً لتطبيق الاستبيان ، واستخدم الباحث استمارة الاستبيان كأداة لجمع البيانات والمعلومات وتم اجراء المعالجات الاحصائية المناسبة لها ، وكانت أهم النتائج هى : (له

- منصة مدرستي الالكترونية تساعد المعلم في استغلال الوقت أكثر من الطريقة التقليدية لتدريس درس التربية البدنية ، وأن المعلم يشعر بالرضى من خلال تدريس درس التربية البدنية عبر منصة

$$
\text { مدرستي الالكترونية بشكل عام • منصن }
$$

- منصة مدرستي الالكترونية تتيح إلى حد ما للمعلم التدريس بكفاءة مع توفير نموذج مثالي للمهارة الحركية أكثر من الطريقة التقليدية لدرس التربية البدنية ، والمعلم إلى حد مـا يستطيع أن يقيم لـئي



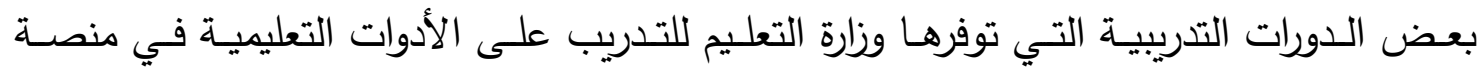




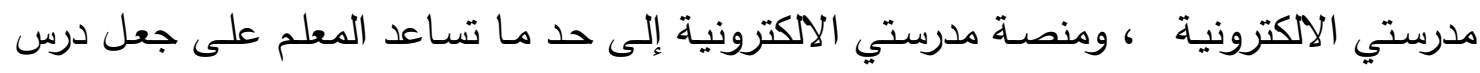

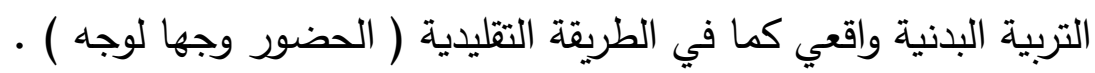

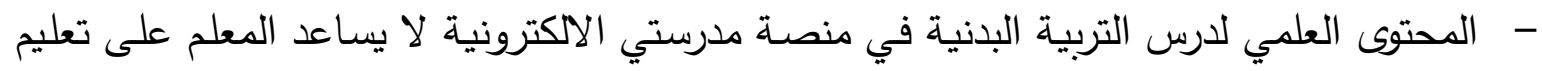

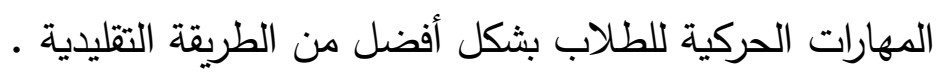
- - من مميزات منصـة مدرستي الالكترونية أثناء درس التربية البدنية أنه يستطيع الطالب طرح أي لئهي

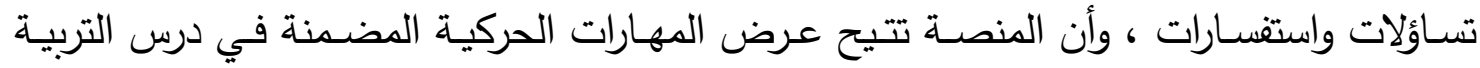

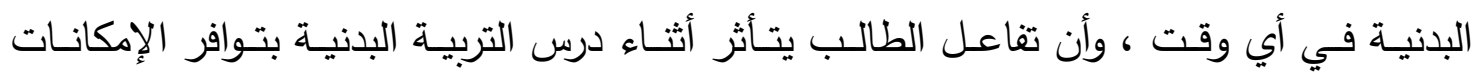
الرياضية الأساسية التي تتوافر في الدرس التقليدى . - منصة مدرستي الالكترونية تساعد إلى حد ما الطالب على أداء المهارات الحركية بسهولة ويسر • الطالب أقل إسـتجابة أثنـاء درس التربيـة البدنيـة على منصـة مدرستي الالكترونيـة مقارنـة بالتدريس بالطريقة التقليدية . 